\title{
Variante A5 de la vía biliar principal durante una colecistectomía laparoscópica
}

\author{
A5 variant of the main bile duct during laparoscopic cholecystectomy
}

Marcelo Sebastian Pontillo-Walerovsky ${ }^{1}$, Carolina Susana Guarneri-Olivieri ${ }^{1}$ y Juan José Cossa-Morchio

Presentamos el caso de una paciente de sexo femenino, 31 años, que durante una colecistectomía laparoscópica de urgencia, se evidencia una variante anatómica de la vía biliar principal (VBP) (Figura $1)$.

Frente a dudas anatómicas de la VBP, se decidió realizar una colangiografía intraoperatoria, con el objetivo de lograr una colecistectomía segura, e intentar minimizar el riesgo de lesión iatrogénica de esta.

Durante la colangiografía certificamos una

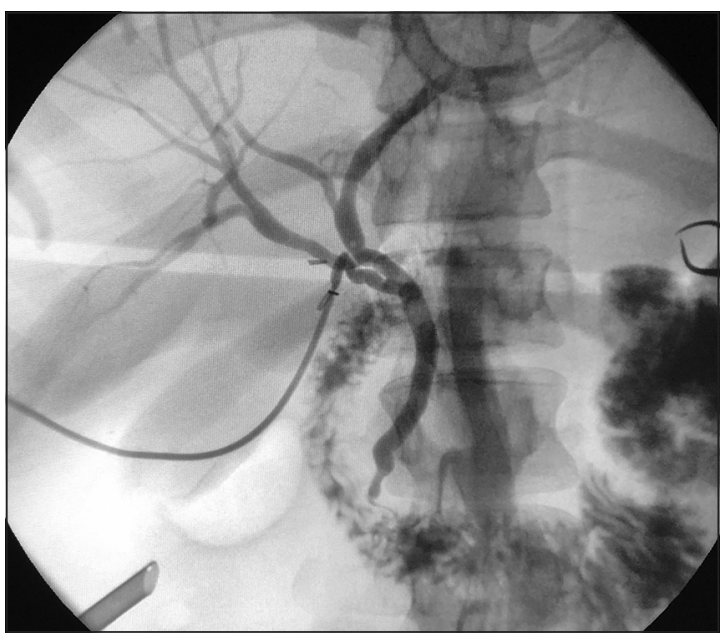

Figura 1. Colangiografía intraoperatoria. variante de la VBP, tipo A5 de la clasificación de Huang, entendiendo por tal, al conducto posterolateral derecho que desemboca en el conducto cístico (Figura 2), cuya frecuencia es menor al 1\% y presenta un alto riesgo de lesión de VBP.

Concluimos que ante la sospecha de una anatomía biliar incierta la colangiografía intraoperatoria permite definir la misma disminuyendo el riesgo de lesión iatrogénica de la VBP. A su vez, permite diagnosticar de forma precoz una lesión de la VBP y eventualmente repararla en el mismo acto operatorio.
Departamento de Emergencia Hospital de Clínicas. Facultad de Medicina. Universidad de la República. Montevideo, Uruguay.

Recibido 2020-12-23, aceptado 2021-01-04

Correspondencia a: Dr. Marcelo S. Pontillo W. marspontillo@gmail.com

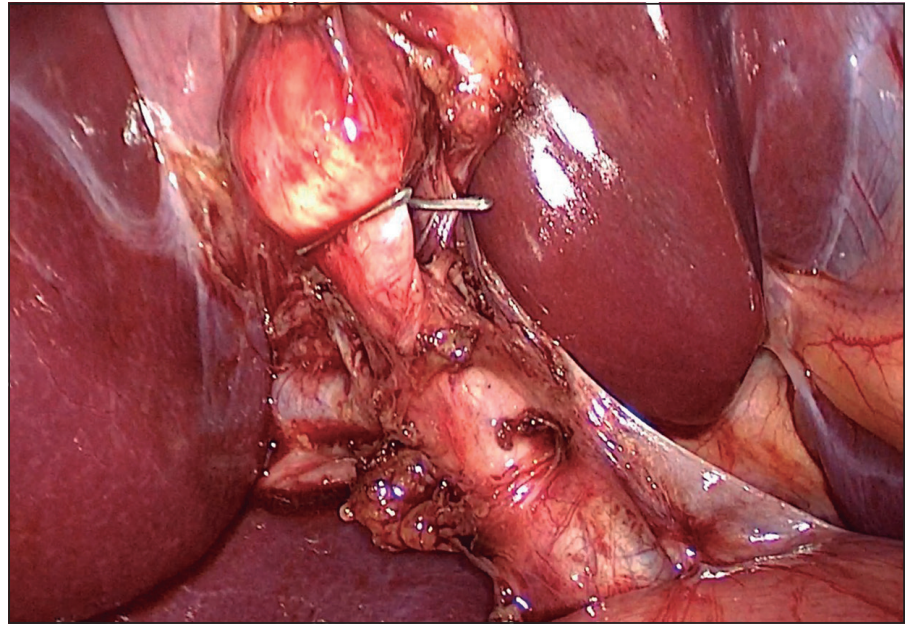

Figura 2. Visión intraoperatoria de pedículo hepático y vesicular disecado. 


\section{IMÁGENES Y CIRUGÍA}

\section{Bibliografía}

1. Chaib E, Fligelman A, Ferreira F et al. Bile duct confluence: anatomic variations and its classification. Surg Radiol Anat.
2013;36:105-9.

2. Nari G, Viotto L, Gil F et al. Bile duct injury of the $\mathrm{F}$ type anatomic anomalies. The importance of the intra-operative cholangiography and therapetical options. Acta Gastroenterol Latinoam. 2015;45:303-6.

3. Rose JB, Hawkins W. Diagnosis and management of biliary injuries. Curr Probl Surg. 2017;54:406-35 